\title{
Rooting of Stem Cuttings with Different Indole 3 Butyric Acid (IBA) Treatments and Development of Micropropagation Protocol for Piper betle L. Node Culture
}

\author{
Qusay Abdulhamza Muttaleb1, Thohirah Lee Abdullah",3, Azmi Abdul Rashid4, \\ Siti Aishah Hassan² \\ ${ }^{1}$ Technical Institute of Babel, Al-Furat Al-Awsat Technical University, Al Hillah, Iraq \\ ${ }^{2}$ Department of Crop Science, Faculty of Agriculture, Universiti Putra Malaysia, Serdang, Malaysia \\ ${ }^{3}$ Laboratory of Plant Microstructure and Anatomy, Department of Crop Science, Faculty of Agriculture, Universiti Putra \\ Malaysia, Serdang, Malaysia \\ ${ }^{4}$ In Vitro Laboratory Department of Agriculture Technology, Universiti Putra Malaysia, Serdang, Malaysia \\ Email: qusayabdulhamza20@gmail.com
}

How to cite this paper: Muttaleb, Q.A., Abdullah, T.L., Rashid, A.A. and Hassan, S.A. (2017) Rooting of Stem Cuttings with Different Indole 3 Butyric Acid (IBA) Treatments and Development of Micropropagation Protocol for Piper betle L. Node Culture. American Journal of Plant Sciences, 8, 3084-3100.

https://doi.org/10.4236/ajps.2017.812208

Received: October 16, 2017

Accepted: November 14, 2017

Published: November 17, 2017

Copyright $\odot 2017$ by authors and Scientific Research Publishing Inc. This work is licensed under the Creative Commons Attribution International License (CC BY 4.0).

http://creativecommons.org/licenses/by/4.0/

(c) (7) Open Access

\begin{abstract}
The present study, conducted during 2016 and 2017 seasons, aimed to investigate the effect of IBA on rooting of Piper betle L. stem cuttings (softwood and semi-hardwood). The experiment was undertaken in misting house field 2 UPM using the sand media to determine the adventitious roots initiation and development using the histological method. The cuttings were treated with different IBA concentrations $(0,500,1000,1500$ and $2000 \mathrm{mg} / \mathrm{L})$. The nodes explants were used in the development of a protocol for in vitro propagation of $P$. betle L., with different concentrations of Clorox with different times of immersion (20\% Clorox 10 minutes, 30\% Clorox 10 minutes, $20 \%$ Clorox 20 minutes, and 30\% 20 minutes). In multiplication of the plantlets, Murashige and Skoog (MS) medium with different concentrations of BAP (0, $0.5,1.0,2.0 \mathrm{mg} / \mathrm{L}$ ) were used to investigate the rooting of the explants. The results indicated that the types of the cuttings were different in the rooting capacity and the length of the roots. Moreover, it was found that in comparison with the control treatment, by a rise in the concentrations of the IBA, there was a significant upsurge in the rooting percentage, the root diameter, and the number of the roots. The results indicated that the types of cutting with 1000,1500 and $2000 \mathrm{mg} / \mathrm{L}$ IBA perform better in the root percentage (100\%) in the semi hardwood cuttings. The best results, however, were 2000 $\mathrm{mg} / \mathrm{L} \mathrm{IBA}$ in the semi hardwood cuttings, with the number of the roots to be 35.05 , and the fresh weight of the roots to be $3.94 \mathrm{~g}$, the dry weight of the
\end{abstract}


roots to be $0.33 \mathrm{~g}$, the length of the roots to be $391.88 \mathrm{~cm}$, the roots diameter to be $1.21 \mathrm{~mm}$, the surface area of the roots to be $121.83 \mathrm{~cm}^{2}$, and the root volume to be $2.99 \mathrm{~cm}^{3}$. Nonetheless, the optimal concentration of Clorox with the time immersion was $20 \%$ with the 20 -minute immersion time, which produced a shoot induction percentage of $30 \%$ dead explants and a mean number of 70.00 shoots per explant and the optimal concentration of benzylaminopurine (BAP) at $1.0 \mathrm{mg} / \mathrm{L}$. It is of note that a shoot induction percentage of $22.29 \%$ and a mean number of $4.1 \%$ number of auxiliary bud per treatment. $P$. betle shoots in MS medium without PGR MS (0.0) yielded a good rooting.

\section{Keywords}

Piper betle, Rooting, Stem Cutting, Indole-3-Butyric Acid, Micropropagation

\section{Introduction}

Piper betle L., an important species of the Piperaceae family, is an evergreen perennial climber with glossy heart-shaped leaves. It grows abundantly in many countries in the South-east Asian region [1]. It is commonly used as a tropical culinary herb or ulam and is often consumed raw in South-east Asian countries, such as Thailand, Malaysia, and Indonesia. It is assumed that the regular intake of the leaves can assist in preventing degenerative diseases, delaying ageing and improving general health [2]. According to various phytochemical studies, $P$. betle contains a wide variety of biologically active compounds whose concentrations depend on the diversity of the plant species [3]. These components are valued as a stimulant for their medicinal properties such as antiplatelet, anti-inflammatory effects as well as immunomodulatory, gastro-protective and antidiuretic activities [4]. $P$. betle is a significant crop in Malaysia, but very few reports are available for this species [5] [6]. P. betle contains compounds active in the biological activities such as anticancer, anti-inflammatory, and immunomodulatory. Hydroxychavicol, allypyrocatechol, methylpiperbetol, as well as piper betel are considered as active compounds separated from leaves and other fractions. In line with this, great antioxidant activities have been exhibited by Phenol-rich leaves of $P$. betle. The fact is that there is scarcity of studies investigating more effective methods of propagation and cultivation which allow progresses in plant breeding or rapid propagation of an enormous quantity of the plants similar to the species [7]. A momentous phase involved in plant vegetative propagation has been claimed to be adventitious root formation. This could be predominantly controlled by genetic, physiological, chemical or even physical factors [8]. There have been numerous researches conducted on investigating the impacts of plant regulators on rooting among different plant species [8] [9] [10]. To regulate the root development, Phytohormones, particularly auxins, contri- 
bute predominantly. Auxins are declared to be engaged in the course of adventitious root formation [11] [12], as well as the interdependent physiological stages encompassing the rooting process which seem to be accompanying the variations in the endogenous auxin levels [13]. Auxins are efficient inducer of adventitious roots in numerous medicine plants [14] [15] [16].

In contrast, micropropagation has been considered as an extensively employed practice, commonly to produce plants having economic prospective. The reason why micropropagation or in vitro plant regeneration from the culture of axillary buds has been reported to be paramount is that it is able to create clones which uphold the properties of the mother plant [17]. The most noteworthy element in acquiring a vast quantity of plantlets via micropropagation is using a suitable culture medium along with formulating the plant growth regulators like cytokinins with the aim of inducing and propagating the in vitro axillary buds [18]. Nevertheless, there is lack of surveys investigating the propagation of $P$. betle so far. For that reason, the current research is undertaken to investigate the effects of IBA on rooting of stem cuttings of $P$. betle and the development of in vitro propagation protocol of $P$. betle node explant.

\section{Materials and Methods}

\subsection{Rooting of the Stem Cuttings with Different Indole 3 Butyric Acid (IBA) Treatments}

Cuttings of $P$. betle were acquired from the Herbal unit TPU, UPM. Different types of cuttings (softwood \& semi-hardwood) and different (IBA) concentrations of IBA [0 (control), 500, 1000, 1500, and $2000 \mathrm{mg} / \mathrm{L}$ IBA] were used method of [19]. The media used for rooting was sand, sieved at $5 \mathrm{~mm}$ and poured $3 / 4$ full in the propagation trays.

The study was carried out in a misting house at field 2, UPM. Both softwood and semi-hardwood cuttings were cut at $20-25 \mathrm{~cm}$ length and $3-4 \mathrm{~mm}$ diameter, while the leaves below the point where 2 - 3 leaves attached to the stem were pinched, and the cuttings were planted in the rooting medium, buried at about $2 / 3$ of length in and plant spacing [20].

The propagation unit was with $70 \%-90 \% \mathrm{RH}$ with $90 \%$ shade: The misting was set at every 15 minutes and at intervals of 45 minutes from 07.00 am to $07.00 \mathrm{pm}$ daily. The cuttings were in the IBA solution at $1-3 \mathrm{~cm}$ on the length of the cuttings for five seconds. Both softwood and semi-hardwood cuttings were subjected to misting for 28 days. Some parameters like the quantity of the roots per cutting, the roots length $(\mathrm{cm})$, fresh and dry weights of the roots $(\mathrm{g})$, the root diameter $(\mathrm{mm})$, the root surface area $\left(\mathrm{cm}^{2}\right)$, and the root volume $\left(\mathrm{cm}^{3}\right)$ were measured by (Win RHIZO, Root scanner model Epson Expression 1680 USA).

The experimental design of the study was based on Randomised Complete Block Design (RCBD) in factorial arrangement with four replications and five cuttings per replication. The factors included five levels $(0 \mathrm{mg} / \mathrm{L}$ (control), 500 , 1000,1500 and $2000 \mathrm{mg} / \mathrm{L}$ ) of the IBA and two types of cuttings (softwood and 
semi-hardwood). The total number of cutting includes 250 (5 concentration, 2 types of cuttings and 5 replications; 125 softwood cuttings and 125 semi-hardwood cuttings). Harvesting was done after 28 days. Prior to the data analysis, the data was subjected to the normality test and the homogeneity of the variance using the Levene Test. The Arcsine transformation was done for the percentage of the rooting which did not pass the homogeneity. The Statistical Analysis System (SAS) (Version 9.4) was utilized to conduct the Analysis of variance (ANOVA). Moreover, the means were compared using the DMRT with the significant level set at $\mathrm{p} \leq 0.05$.

\subsection{Adventitious Roots Initiation and Development (Root Anatomy and Histology)}

The process of rooting of this plant was observed to determine the formation of the adventitious roots. We obtained the roots from the stems' basal portion that showed root initiation. The procedure included different stages namely fixing, dehydrating, embedding, sectioning, de- waxing and staining [21]. To do histological investigations, we gathered basal segments $(0.5 \mathrm{~cm})$ from the treatments on Days $0,3,6,9,12$, and 15. We gathered 10 samples every three days. Moreover, we repeated the whole experiment (with the exception of day 0 ). The stems were fixed in a mixture including formalin, glacial acetic acid (FAA) and 50\% ethanol [1:1:18 (v/v/v)], dehydrated consistent with [22]) and [23], via a graded $n$-butanol series and embedded in paraffin $n$ wax. Sections of $8-10 \mu \mathrm{m}$ were cut and stained Safranin 0-fast green (FCF) for the general examination [24]. Stained specimens could be observed under a compound light microscope attached to a digital camera, and all the images were captured and saved in the attached computer.

\subsection{Development of the Explant Sterilization Procedure for Micropropagation of $P$. betle Node Culture}

\subsubsection{Reducing Microbial Contamination and Increasing the Explant Survival by Clorox Treatment}

Node explants (1 - $2 \mathrm{~cm}$ length) were excised from $P$. betle plants previously grown in the pots and washed under running tap water and later with a detergent solution for $10 \mathrm{~min}$. The explants were surface sterilised using two Clorox concentrations (20\% and $30 \%$ ) and two immersion times (20 and 30 minutes). The explants were subsequently washed 3 - 4 times using sterile distilled water. We cultured the node explants in [25] a medium under aseptic conditions. We incubated all the cultures at $25^{\circ} \mathrm{C}+2^{\circ} \mathrm{C}$ with $16 \mathrm{~h}$ photoperiod provided by cool florescent tubes giving a light intensity of $30 \mathrm{umol} / \mathrm{m}^{2} / \mathrm{sec}$. Several parameters including shoot induction, fungal contamination (\%), bacterial contamination (\%), explant browning (\%), dead explants (\%), and survived explants (\%) were measured after four weeks of culture. The experiment was undertaken using a Randomised Complete Block Design (RCBD), two concentrations, two immersion times, and ten replications. 


\subsubsection{Determination of the Optimum BAP Concentration in Inducing Shoots Multiplication from the Node Culture of $P$. betle}

The nodes from the survived cultures from the previous sterilisation procedure were used in this experiment. The node explants were subcultured in the Murashige and Skoog medium with different concentrations of $\operatorname{BAP}(0,0.5,1.0,2.0$ and $5.0 \mathrm{mg} / \mathrm{L}$ ). The explants were cultured in $100 \mathrm{ml}$ flasks and incubated in a culture room at $25^{\circ} \mathrm{C}+2^{\circ} \mathrm{C}$ with a $16 \mathrm{~h}$ photoperiod provided by cool fluorescent tubes giving a light intensity of $30 \mathrm{umol} / \mathrm{m}^{2} / \mathrm{sec}$. The parameters measured included the shoot induction, shoot multiplication; the number of the axillary buds, the height of the plant $(\mathrm{cm})$, the quantity of the leaves as well as the quantity of the roots. By employing a Randomised Complete Block Design (RCBD), we conducted the experiment with ten replications. The data on the percentage of the explants rooted and the number of the roots produced were recorded after five weeks of culture.

\section{Results}

\subsection{The Results of the Rooting Study}

\subsubsection{The Percentage of Rooting (\%)}

Table 1 demonstrates that the type of cutting had a significant effect on the percentage of rooting. The highest percentage (100\%) was found under 1000, 1500, $2000 \mathrm{mg} / \mathrm{L}$ IBA concentrations in the semi softwood cuttings. In the softwood cuttings, the highest percentage (100\%) was found in $2000 \mathrm{mg} / \mathrm{L}$ IBA treatment. The lowest percentage $(68.75 \%)$ was in the control treatment in both semi hardwood and softwood cuttings (66.25\%).

\subsubsection{The Number of the Roots}

The root number was taken by visually counting the number of the roots. The

Table 1. Mean comparison of the root percentages, the root number, the dry root weight and the fresh root weight on of $P$. betle L. as affected by different concentrations of Indole 3 Butyric Acid (IBA) and the types of cuttings (softwood and semi-hardwood).

\begin{tabular}{cccccc}
\hline Types of cuttings & IBA mg/L & Roots percentage (\%) & Number of roots & Fresh weight of roots $(\mathrm{g})$ & Dry weight of roots $(\mathrm{g})$ \\
\hline & Control 0 & $66.25 \pm 4.78 \mathrm{~d}$ & $11.9 \pm 2.024 \mathrm{~g}$ & $1.48 \pm 0.20 \mathrm{i}$ & $0.079 \pm 0.016 \mathrm{~h}$ \\
& 500 & $75.00 \pm 5.77 \mathrm{c}$ & $18.75 \pm 2.10 \mathrm{e}$ & $2.15 \pm 0.20 \mathrm{~g}$ & $0.146 \pm 0.019 \mathrm{f}$ \\
$\begin{array}{c}\text { Softwood } \\
\text { cuttings }\end{array}$ & 1000 & $90.00 \pm 4.08 \mathrm{~b}$ & $23.95 \pm 2.44 \mathrm{c}$ & $2.72 \pm 0.47 \mathrm{ef}$ & $0.207 \pm 0.020 \mathrm{~d}$ \\
& 1500 & $91.00 \pm 4.78 \mathrm{~b}$ & $24.85 \pm 2.70 \mathrm{c}$ & $2.88 \pm 0.37 \mathrm{de}$ & $0.230 \pm 0.029 \mathrm{c}$ \\
& 2000 & $100.00 \mathrm{a}$ & $28.15 \pm 2.68 \mathrm{~b}$ & $3.33 \pm 0.37 \mathrm{~b}$ & $0.287 \pm 0.023 \mathrm{~b}$ \\
& Control 0 & $68.75 \pm 4.78 \mathrm{~d}$ & $14.15 \pm 1.63 \mathrm{f}$ & $1.79 \pm 0.13 \mathrm{~h}$ & $0.112 \pm 0.014 \mathrm{~g}$ \\
Semi-hardwood & 500 & $80.00 \pm 4.08 \mathrm{c}$ & $20.40 \pm 1.39 \mathrm{~d}$ & $2.55 \pm 0.22 \mathrm{f}$ & $0.168 \pm 0.016 \mathrm{e}$ \\
cuttings & 1000 & $100.00 \mathrm{a}$ & $27.00 \pm 2.47 \mathrm{~b}$ & $3.04 \pm 0.26 \mathrm{~cd}$ & $0.239 \pm 0.035 \mathrm{c}$ \\
& 1500 & $100.00 \mathrm{a}$ & $28.15 \pm 2.13 \mathrm{~b}$ & $3.13 \pm 0.46 \mathrm{c}$ & $0.248 \pm 0.050 \mathrm{c}$
\end{tabular}

The values are the means \pm SE. of 5 replications; the means having identical letters were found not to be significantly different at $\mathrm{p} \leq 0.05$ in line with DMRT. 
average roots number was significantly $(\mathrm{p}<0.05)$ influenced by different IBA concentrations and varied in different stem cuttings (Table 1 ). The highest root number $(35.05 \pm 2.70)$ was obtained in the hardwood cuttings under $2000 \mathrm{mg} / \mathrm{L}$ IBA treatment. The bottommost root number could be found in the softwood cuttings with $0 \mathrm{mg} / \mathrm{L}$ IBA $(11.9 \pm 2.024)$ (Figure 1$)$. These results indicate that no significant difference could be detected between $1000 \mathrm{mg} / \mathrm{L}$ IBA and, 1500 $\mathrm{mg} / \mathrm{L}$ IBA in semi-hardwood cuttings and $2000 \mathrm{mg} / \mathrm{L}$ IBA in softwood cuttings (Table 1).

\subsubsection{The Fresh Weight of the Roots (g)}

The result on the fresh weight of the roots has been exhibited in Table 1. The semi hardwood cutting supper most result was $(3.94 \pm 0.25 \mathrm{~g})$ at $2000 \mathrm{mg} / \mathrm{L} \mathrm{IBA}$, whereas the lowest result shown in the control treatment in the softwood cuttings was $1.48 \pm 0.20 \mathrm{~g}$.

\subsubsection{The Dry Weight of the Roots (g)}

The root samples were oven-dried at $70^{\circ} \mathrm{C}$ for $72 \mathrm{hr}$ and were weighed using an electronic balance. Table 1 shows that the maximum root dry weight was observed in the semi hardwood cuttings $(0.328 \pm 0.03)$ at $2000 \mathrm{mg} / \mathrm{L}$ while the lowest root dry weight was observed in the softwood cuttings $(0.079 \pm 0.01)$ at 0 $\mathrm{mg} / \mathrm{L}$ IBA.
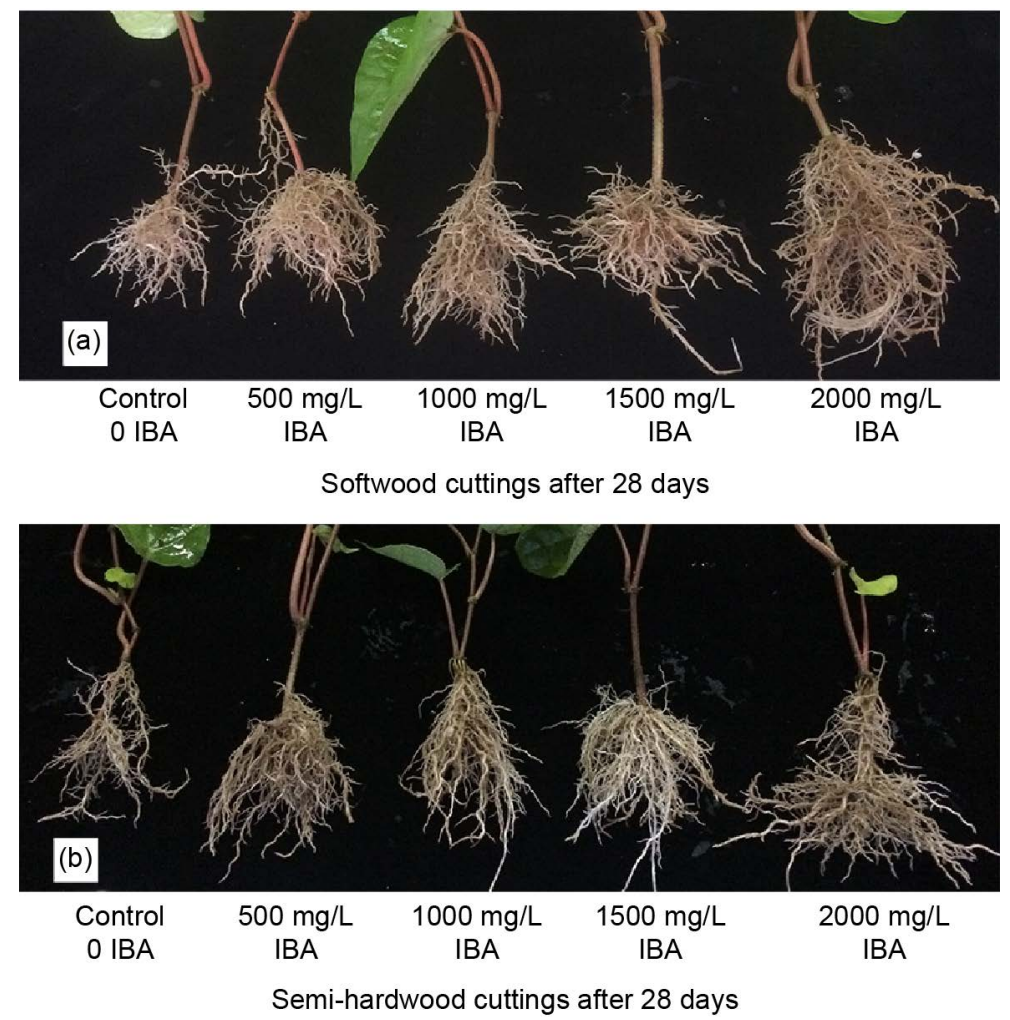

Figure 1. The effect of different IBA concentrations on the types of cuttings. (a): Softwood cuttings and (b): Semi hardwood cuttings after 28 days of treatment. 


\subsubsection{The Roots Length $(\mathrm{cm})$}

The results in Table 2 indicated that the IBA concentrations significantly affected the length of roots. The maximum roots length could be observed in 2000 $\mathrm{mg} / \mathrm{L} \mathrm{IBA}(391.88 \pm 3.51 \mathrm{~cm})$ in the semi hardwood cuttings; on the other hand, the bottommost mean of the root length was recorded in the control treatment in the softwood cuttings $(190.92 \pm 3.61 \mathrm{~cm})$.The results showed that $2000 \mathrm{mg} / \mathrm{L}$ IBA had the highest length of the roots in both types of cuttings and $0 \mathrm{mg} / \mathrm{L} \mathrm{IBA}$ had the lowest length which might be due to the interactions between both types of cuttings and the levels of the auxin (Table 2).

\subsubsection{The Diameter of the Roots ( $\mathrm{mm}$ )}

The results in Table 2 showed that the types of cuttings exerted a significant influence on the roots' diameters. The highest root diameter was observed in the semi-hardwood cuttings $(1.21 \pm 0.042 \mathrm{~mm})$ at IBA $2000 \mathrm{mg} / \mathrm{L}$. The softwood cutting without the IBA had the least diameter of the roots $(0.68 \pm 0.031 \mathrm{~mm})$. No significant difference could be observed between 1500 and $2000 \mathrm{mg} / \mathrm{L}$ IBA treatments (Figure 1).

\subsubsection{The Surface Area of the Roots $\left(\mathrm{cm}^{2}\right)$}

Cuttings treated with the IBA exerted a significant effect on the surface area of the roots in the semi hardwood cuttings. The maximum surface area in 2000 $\mathrm{mg} / \mathrm{L}$ IBA was $121.83 \pm 3.26 \mathrm{~cm}^{2}$ while the control treatment had the lowest mean $53.42 \pm 3.58 \mathrm{~cm}^{2}$ softwood cuttings (Table 2).

\subsubsection{The Root Volume $\left(\mathrm{cm}^{3}\right)$}

Table 2 showed that the IBA concentrations significantly affected the volume of the roots. The highest volume was observed in $2000 \mathrm{mg} / \mathrm{L}$ IBA $(2.99 \pm 0.046$ $\mathrm{cm}^{3}$ ) in the semi hardwood cuttings. The lowest volume was in the control

Table 2. Mean comparison of the root length, the root diameter, the rooting surface, the root and the root volume of Piper betle L. among different concentrations of Indole 3 Butyric Acid (IBA) and the types of cuttings (softwood and semi-hardwood).

\begin{tabular}{cccccc}
\hline Types of cuttings & IBA mg/L & Roots Length $(\mathrm{cm})$ & Root Diameter $(\mathrm{mm})$ & Surface Area of roots $\left(\mathrm{cm}^{2}\right)$ & Root Volume $\left(\mathrm{cm}^{3}\right)$ \\
\hline & Control 0 & $190.92 \pm 3.61 \mathrm{j}$ & $0.68 \pm 0.031 \mathrm{e}$ & $53.42 \pm 3.58 \mathrm{i}$ & $1.19 \pm 0.043 \mathrm{~h}$ \\
$\begin{array}{c}\text { Softwood } \\
\text { cuttings }\end{array}$ & 500 & $249.82 \pm 3.05 \mathrm{~h}$ & $0.76 \pm 0.030 \mathrm{~d}$ & $76.29 \pm 3.98 \mathrm{~g}$ & $1.71 \pm 0.036 \mathrm{f}$ \\
& 1000 & $297.33 \pm 3.91 \mathrm{f}$ & $0.85 \pm 0.033 \mathrm{c}$ & $88.47 \pm 3.32 \mathrm{e}$ & $1.99 \pm 0.043 \mathrm{de}$ \\
& 1500 & $313.26 \pm 4.62 \mathrm{e}$ & $0.86 \pm 0.032 \mathrm{c}$ & $92.97 \pm 4.35 \mathrm{~d}$ & $2.01 \pm 0.047 \mathrm{~d}$ \\
& 2000 & $344.65 \pm 4.88 \mathrm{~b}$ & $0.96 \pm 0.026 \mathrm{~b}$ & $102.91 \pm 3.88 \mathrm{~b}$ & $2.32 \pm 0.037 \mathrm{~b}$ \\
& Control 0 & $226.05 \pm 3.33 \mathrm{i}$ & $0.75 \pm 0.029 \mathrm{~d}$ & $68.16 \pm 3.77 \mathrm{~h}$ & $1.36 \pm 0.045 \mathrm{~g}$ \\
Semi-hardwood & 500 & $291.58 \pm 3.87 \mathrm{~g}$ & $0.85 \pm 0.028 \mathrm{c}$ & $84.18 \pm 3.86 \mathrm{f}$ & $1.98 \pm 0.050 \mathrm{e}$ \\
cuttings & 1000 & $325.10 \pm 3.24 \mathrm{~d}$ & $0.95 \pm 0.070 \mathrm{~b}$ & $100.37 \pm 3.96 \mathrm{c}$ & $2.21 \pm 0.041 \mathrm{c}$ \\
& 1500 & $334.66 \pm 3.57 \mathrm{c}$ & $0.97 \pm 0.039 \mathrm{~b}$ & $104.98 \pm 3.44 \mathrm{~b}$ & $2.34 \pm 0.037 \mathrm{~b}$ \\
& 2000 & $391.88 \pm 3.51 \mathrm{a}$ & $1.21 \pm 0.042 \mathrm{a}$ & $121.83 \pm 3.26 \mathrm{a}$ & $2.99 \pm 0.046 \mathrm{a}$ \\
\hline
\end{tabular}

The values are the means \pm SE. of 5 replications, the means with identical letter did not significantly differ at $\mathrm{p} \leq 0.05$ in line with DMRT. 

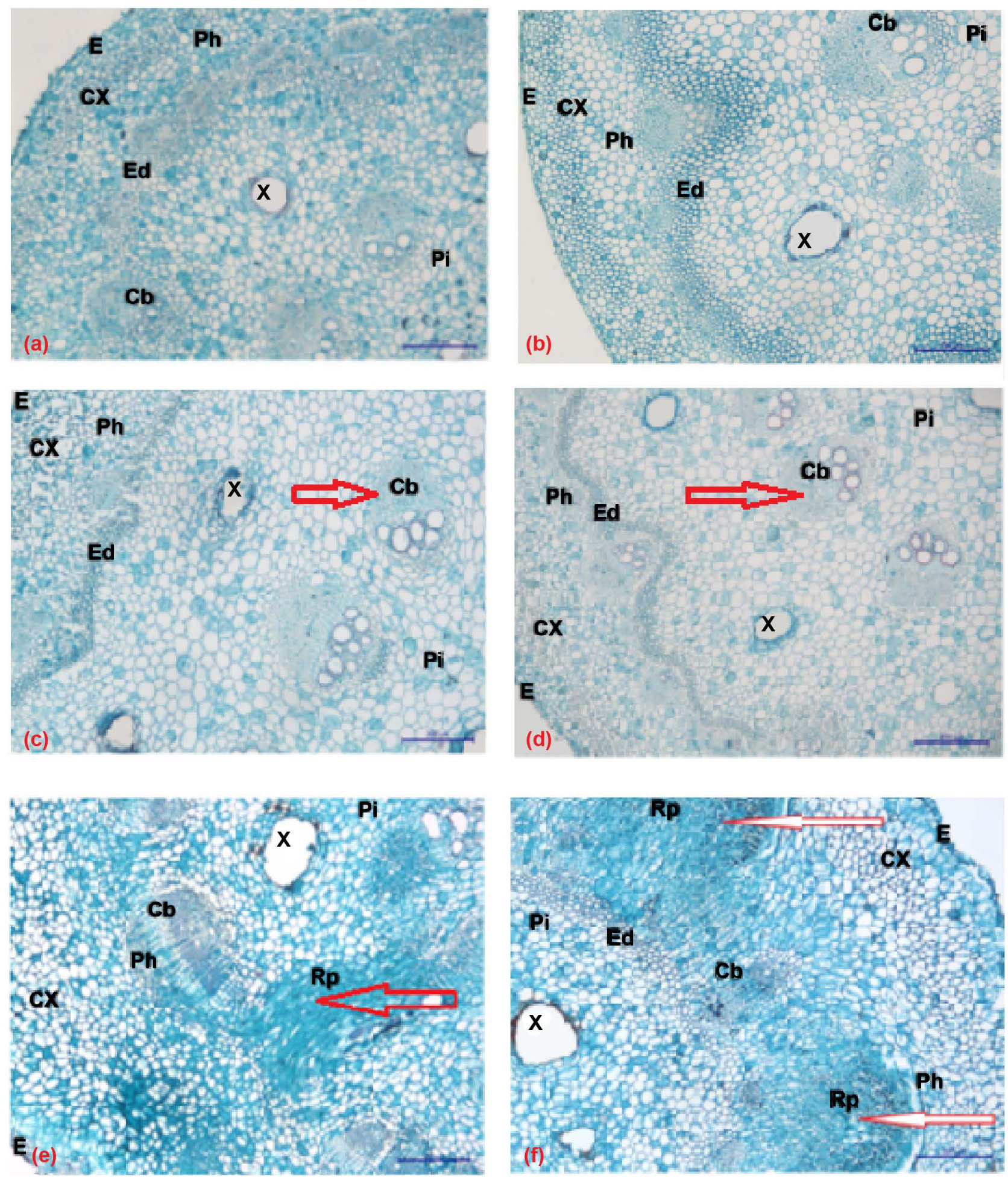

Figure 2. Cross section of the stem of P. betle L. (X4) showing, Epidermis (E) cortex (Cx). Endodermis (Ed), phloem (Ph), vascular cambium (Cb), xylem (X), and pith (Pi). (a): Cross section of stem 0 day of softwood. (b): Cross section of stem 0 day of semi-hardwood. (c): Cross section of the stem 3 days of softwood showing differentiation to root initials occurring near the vascular bundle (arrow). (d): Cross section of the stem 3 days of semi-hardwood showing development to root initials occurring near the vascular bundle (arrow). (e): Cross section of the stem 6 days of softwood showing some development of root initials organized root primordial (Rp) (arrow). (f): Cross section of the stem 6 days of semi-hardwood showing subsequent development of root initials organized root primordial (Rp) (arrow). 
treatment in the softwood cuttings $\left(1.19 \pm 0.043 \mathrm{~cm}^{3}\right)$. These results revealed that that there was no significant difference between both types of cuttings at $1500 \mathrm{mg} / \mathrm{L}$ IBA in the semi hardwood cuttings and at $2000 \mathrm{mg} / \mathrm{L} \mathrm{IBA}$ in the softwood cuttings (Figure 2).

\subsection{The Results of the Histological Study}

Figure 2(a) and Figure 2(b) clearly showed the cross section of the stem of $P$. betle on day 0 (epidermis, cortex, endodermis, phloem, vascular cambium, xylem, and pith). The cross sections show development in both types of cuttings. Figure 3 reveals the cross section of the stem of $P$. betle on day 3; the cells show dedifferentiation (semi softwood) and development of the softwood cuttings to root initials occurring near the vascular bundle, epidermis, cortex, endodermis, phloem, vascular cambium, xylem and pith. Figure 4 indicates the cross section of the stem of $P$. betle subsequent development of the root initials organized, root primordial (arrow); epidermis, cortex, endodermis, phloem, vascular cambium, xylem, and pith.

\subsection{The Results of the Tissue Culture Study}

\subsubsection{The Effect of Different Clorox Concentrations with Different Immersion Times on the Explants of $P$. betle}

The ANOVA showed that the effect of $20 \%$ and $30 \%$ Clorox with 20 minutes was statistically significant on sterilisation while the effect of $20 \%$ and $30 \%$ Clorox with
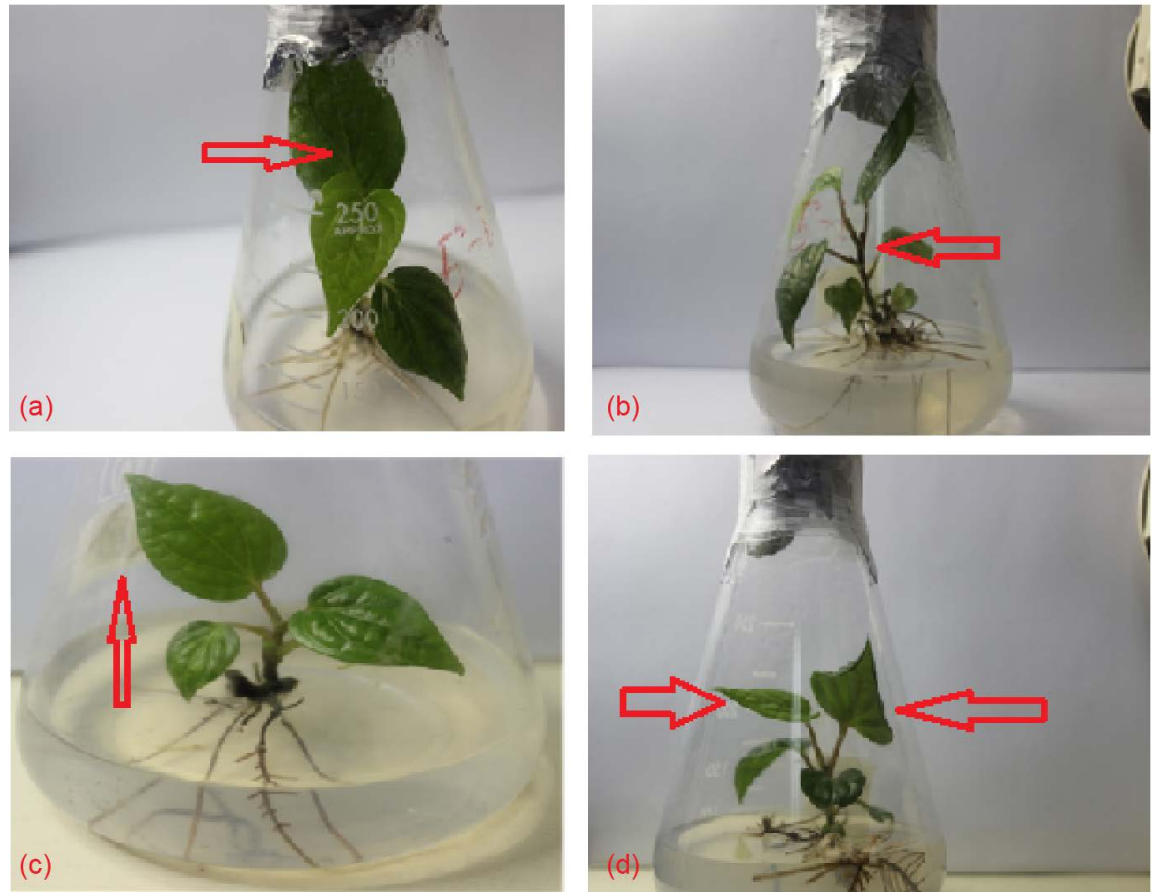

Figure 3. The impact of the BAP in combination with shoot regeneration of $P$. betle. (a) \& (c) Number of the explant with new leaves (arrow), (b) Percentage of the axillary buds (arrow), and (d) Number of leaves (arrow) produced per explant after ten weeks of culture. 
Rooting of $P$. betle shoots in the MS medium without Plant Growth Regulators (PGR).

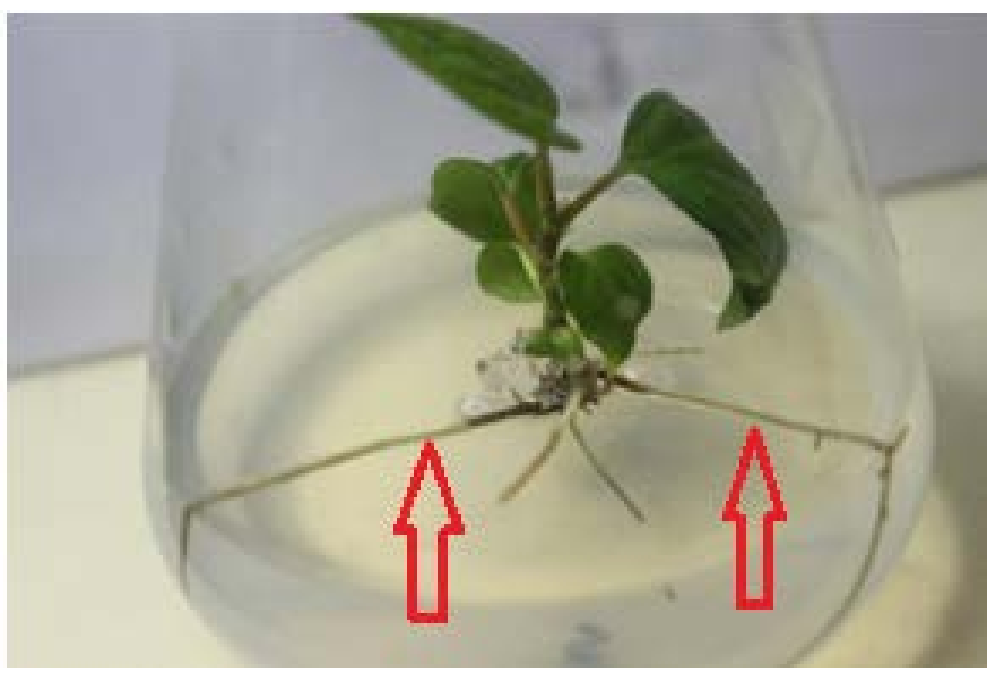

Figure 4. Rooting explant of $P$. betle in (0.0 MS).

10 minutes immersion was not statistically significant. The interaction between Clorox concentrations with different times of immersion was significant. The coefficient of the variation for all the parameters ranged between $6.24 \%-13.19 \%$ which was acceptable. Table 2 demonstrates the results of the mean comparison test. In all the parameters, the highest sterilisation was observed at 20\% and 30\% Clorox with 20 minutes immersion. At 20\% Clorox with 10 minutes and Clorox $30 \%$ with 10 minutes, there was no significant difference. There was no significant difference between 20\% Clorox with 20 minutes and 30\% Clorox with 20 minutes immersion dead explants. $20 \%$ Clorox with 20 minutes was statistically higher than the other treatments for all the parameters.

\subsubsection{The Impact of Diverse Concentrations of Benzyl Adenine Purine (BAP) on the Explant of P. betle}

The ANOVA revealed that the effect of $1.0 \mathrm{mg} / \mathrm{L}$ was statistically significant on all the parameters while the effect at the control treatment, 0.5 and $2.0 \mathrm{mg} / \mathrm{L}$, was not statistically significant on sterilisation. The coefficient of the variation for all the parameters ranged between $17.57 \%-29.75 \%$ which was acceptable. Table 3 shows the results of the mean comparison test. In the parameters, it was observed that at $1.0 \mathrm{mg} / \mathrm{L}$, the BAP was significant. While it was not significant at the control treatment, 0.5 and $2.0 \mathrm{mg} / \mathrm{L} ., 1.0 \mathrm{mg} / \mathrm{L}$ of the BAP was statistically higher than the other treatments for all the parameters.

\section{Discussion}

Semi-hardwood cutting resulted in the maximum average dry weight and root number. The reason for this is attributed to the fact that the semi hardwood cutting encompassed more stored carbohydrate in opposition to the softwood. By a rise in the IBA concentrations, there was a corresponding upsurge in the root percentage. This was due to the fact that applying IBA on the cutting accelerated 
Table 3. Mean comparison among the treatments for the effect of different concentrations of benzyl aminopurine (BAP) on the explants of $P$. betle.

\begin{tabular}{|c|c|c|c|c|}
\hline $\begin{array}{l}\text { Treatment BAP } \\
(\mathrm{mg} / \mathrm{L})\end{array}$ & $\begin{array}{l}\text { Explant With New Leaves } \\
(\% \pm S D)\end{array}$ & $\begin{array}{l}\text { Number of Axillary Bud } \\
\quad(\text { Mean } \pm \text { SD })\end{array}$ & $\begin{array}{c}\text { Number of Leaves Per explant } \\
(\text { Mean } \pm \text { SD) }\end{array}$ & $\begin{array}{l}\text { Number of Roots } \\
\text { (Mean } \pm \text { SD) }\end{array}$ \\
\hline $0.0 \mathrm{BAP}$ & $0.7 \pm 0.5 c$ & $0.7 \pm 0.5 \mathrm{~d}$ & $3.7 \pm 0.8 c$ & $2.2 \pm 0.6 \mathrm{~d}$ \\
\hline $0.5 \mathrm{BAP}$ & $1.9 \pm 0.7 \mathrm{~b}$ & $1.5 \pm 0.5 c$ & $4.5 \pm 0.7 b c$ & $3.9 \pm 0.9 c$ \\
\hline $1.0 \mathrm{BAP}$ & $4.5 \pm 0.8 \mathrm{a}$ & $4.1 \pm 0.7 \mathrm{a}$ & $7.2 \pm 1.0 \mathrm{a}$ & $7.9 \pm 1.0 \mathrm{a}$ \\
\hline $2.0 \mathrm{BAP}$ & $2.4 \pm 0.5 b$ & $2.8 \pm 0.8 \mathrm{~b}$ & $5.2 \pm 1.1 b$ & $6.3 \pm 1.2 b$ \\
\hline
\end{tabular}

The Values are the means \pm SE. of 5 replications, the Means with the same letter are not significantly different at $\mathrm{p} \leq 0.01$ according to DMRT.

the root initiation, elevating the rooting uniformity. Moreover, there was a boost in the quantity of the root once there was a rise in IBA concentrations in both experiments in all kinds of cuttings [26]. Likewise, there was a growth in the root percentage corresponding to any rise in IBA concentrations. This is attributed to the use of IBA increased root percentage which speeded the root initiation, elevating the rooting uniformity. Furthermore, there was an upsurge in the root quantity once IBA concentrations underwent a rise in both experiments for all kinds of cuttings. Consistent with [27], applying IBA could give a rise to the quantity of the roots.

Auxin has been known as an ingredient created in one tissue (shoots) and migrated with the aim of influencing the development of another tissue; in this case the lower portion of stem cuttings. Auxin is able to stimulate cell elongation while having a range of other growth-regulating impacts. It has been asserted by Noor Camellia et al. (2009) the impact of the auxin is exclusive.

Adventitious rooting and shooting in leaf-cuttings of $P$. betle, examining the role of growth hormones on rooting and shooting responses. This was undertaken under individual and combined treatments of the hormones. We observed that in opposition to their individual impact on rooting, IBA in combination was more efficient. Our results are congruent with the findings on adventitious rooting in stem cuttings of numerous crops [28].

Different concentrations of IBA and types of cuttings could exert impacts on the roots quantity and length. More roots were produced from semi-hardwood cuttings treated with $2000 \mathrm{mg} / \mathrm{L} \mathrm{IBA}$ as compared to the roots per plant from semi hardwood and softwood cuttings without any IBA treatments. The IBA is a root promoting the hormone which helps root induction. The increase in the trend in the number of the roots with the increase in the IBA concentrations up to $2000 \mathrm{mg} / \mathrm{L}$ shows a positive response. Similar results were also reported by [26]. Most softwood and semi-hardwood cuttings decayed and a high rooting performance was observed. The misting system with intermittent mists was supplied every 15 minutes at 45 minutes intervals from 7:00 am to 7:00 pm daily. It was believed that over watering causing the humidity in the mist house to be very suitable. High humidity caused the problem of disease [29].

Histological study showed that the IBA treatment stimulated root initiation in 
$P$. betle. The meristematic activity in phloem parenchyma cells preceded the formation of the adventitious roots. On day 0 , no root primordia were initiated in the non-treated cuttings (Figure 2(a) and Figure 2(b)). The Phloem parenchyma cells adjacent to the vascular cambium divided and produced adventitious roots. These results indicate that phloem parenchyma cells in $P$. betle were able to dedifferentiate and became meristematic (Figure 2(c)). This observation is consistent with the previous studies [30] [31] [32] [33]. Three days were required to observe the development of root primordia after the lag phase in $P$. betle treated with $1000 \mathrm{mg} / \mathrm{L}$ IBA, which demonstrated that primordia developed rapidly once cell division was initiated (Figure $2(\mathrm{~d})$ ). On day 6, root primordia were present in the cuttings treated with $1000 \mathrm{mg} / \mathrm{L}$ IBA, suggesting that this treatment accelerated the primordia formation. On day 3 , all the cuttings treated with the IBA had primordia that emerged through the phloem fibres. By day 6, root primordia were absent in the non-treated cuttings, which explain why the non-treated cuttings were difficult to root before six days [34] (Figure 2(e) and Figure 2(f)). This may be due to the higher carbohydrate content of the semi hardwood cutting providing the developing cells with greater supply of energy [35].

In the tissue culture study, sterilization of the explants is one of the major steps for effective in vitro micropropagation. The step can be undertaken by using different agents like calcium hypochlorite, sodium hypochlorite, ethanol, mercuric chloride, hydrogen peroxide or silver nitrate [36]. Generally, the type of the explants showed the main component where internodes were more preferred compared to the shoots apex. The survival rate reached $35 \%$ for the internodes compared to the shoots apex which was only $5 \%$. The successful sterilization was essential for micropropagation and obtaining reduced or contamination free explants [37]. However, selection of the sterilizing agent depends on the type of the explants depending on the morphological characteristics like softness or hardness of the tissue [38]. In this study, using the shoots apex was not suitable due to the softness that could injure the tissue, where the explants would become necrotic and die. [39] showed the same result was obtained for shoots initiation, where internodes cultured on MS medium encompassing 1 $\mathrm{mg} / \mathrm{L} \mathrm{BAP}$ give the highest at $20 \%$ Clorox 20 min, respectively (Figure 5 ). It was higher compared to the time when nodes were used as explants. The browning problem is a result of phenolic compounds secretion which inhibits micropropagation. Almost the explants showed 21\% browning problem in 20\% Crolox 10 min (Table 4). However, the stem of Pelargonium radula explants performed the best on shoot initiation. Manickavasagam et al. (2004) reported that with the $1 \mathrm{mg} / \mathrm{L}$ BAP produced the highest number of shoot from stem explants. The explants produce axillary buds then converted into seedlings [40]. As reported by [41], the node explants of gypsophila originating from the first internodes regenerated more shoots at ranges $74 \%-100 \%$. They also found that the best shoots per explants up to 19 regenerated from the top internodes. As a result, the BAP (1.0 

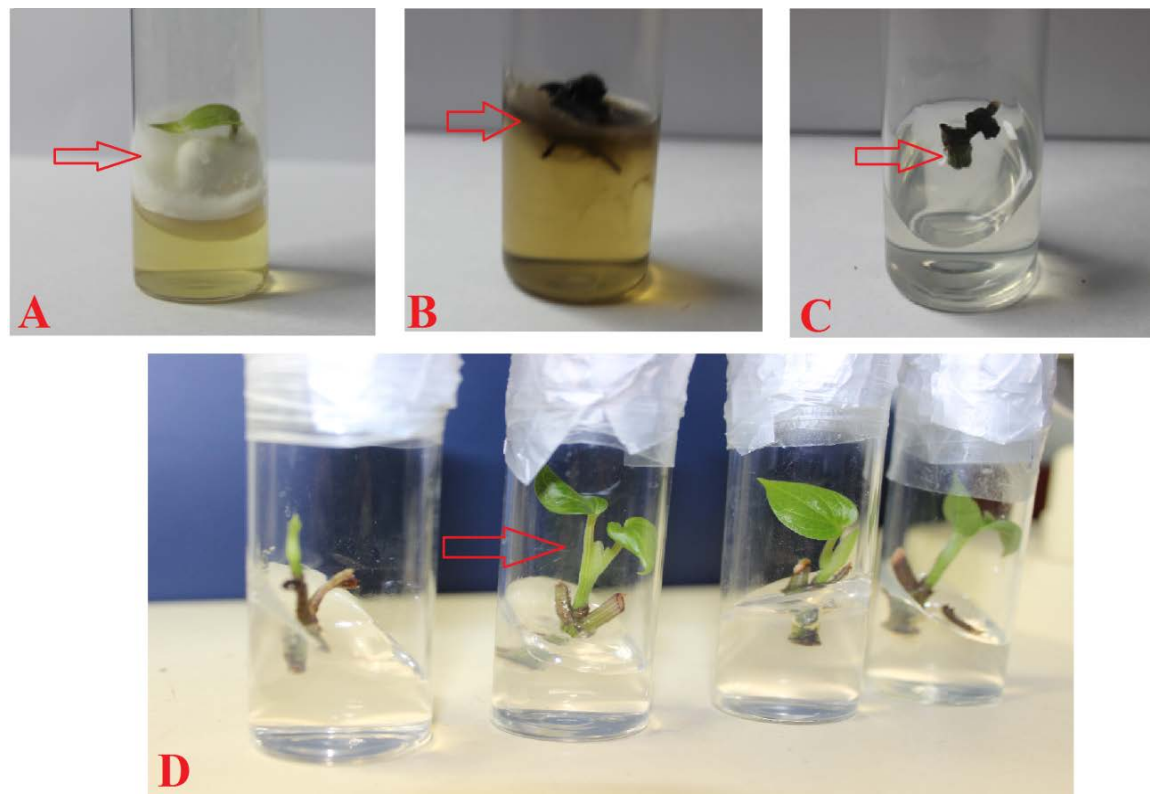

Figure 5. The effect of different Clorox concentrations and different immersion times on $P$. betle explants after five weeks of culture. (a) Fungal, (b) Bacterial contaminations and Browning, (c) Dead explant, and (d) Survival.

Table 4. Mean comparison among the treatments for the effect of different concentrations of Clorox with various immersion times for the sterilisation explant of $P$. betle $\mathrm{L}$.

\begin{tabular}{cccccc}
\hline Concentration \& Time & Fungus & Bacteria & Browning & Dead & Survive \\
\hline Clorox 20\% 10 min & $32.5 \pm 3.0 \mathrm{a}$ & $33.0 \pm 3.8 \mathrm{a}$ & $21.0 \pm 3.8 \mathrm{a}$ & $71.0 \pm 3.8 \mathrm{a}$ & $29.0 \pm 3.8 \mathrm{c}$ \\
Clorox 30\% 10 min & $24.5 \pm 1.0 \mathrm{~b}$ & $28.0 \pm 4.9 \mathrm{ab}$ & $15.0 \pm 2.6 \mathrm{~b}$ & $62.0 \pm 4.3 \mathrm{~b}$ & $38.0 \pm 4.3 \mathrm{~b}$ \\
Clorox 20\% 20 min & $19.0 \pm 2.6 \mathrm{c}$ & $23.0 \pm 3.8 \mathrm{bc}$ & $9.0 \pm 1.2 \mathrm{c}$ & $30.0 \pm 2.3 \mathrm{c}$ & $70.0 \pm 2.3 \mathrm{a}$ \\
Clorox 30\% 20 min & $17.0 \pm 3.8 \mathrm{c}$ & $22.0 \pm 3.7 \mathrm{c}$ & $9.5 \pm 3.0 \mathrm{c}$ & $69.0 \pm 2.6 \mathrm{a}$ & $31.0 \pm 2.6 \mathrm{c}$ \\
\hline
\end{tabular}

The values are the means \pm SE. of 5 replications, the means with identical letter do not significantly differ at $\mathrm{p} \leq 0.01$ according to DMRT.

$\mathrm{mg} / \mathrm{l}$ ) showed the optimum plant growth regulator compared to $0.5,2.0 \mathrm{mg} / \mathrm{L}$ of the BAP in shoot initiation at the early stage.MS medium supplemented with 1.0 $\mathrm{mg} / \mathrm{l} \mathrm{BAP}$ was more efficient in promoting the shoot in propagation of the explants [42] [43]. [44] also underscored the importance of the BAP for regeneration of in vitro plant. Furthermore, [43] studied the medicinal herb and reported that MS supplemented with $1.0 \mathrm{mg} / \mathrm{L}$ BAP showed the best results (100\%) with multiple shoots formed.

\section{Conclusions}

The results of this investigation indicated that the stem cuttings of $P$. betle cultivar significantly affected the percentage of rooting and the roots number. The fresh and dry weights of the roots, the length of the roots diameter, the surface area of the root and the roots volume in the softwood cuttings, and the concentrations of the auxin significantly affected (IBA 1000 and 1500, $2000 \mathrm{mg} / \mathrm{L}$ ) the 
rooting percentage in the semi-hardwood cuttings and only at $2000 \mathrm{mg} / \mathrm{L} \mathrm{IBA}$ in the semi-hardwood cuttings.

In addition, the best development of the meristematic activity and the phloem parenchyma cells was initiated appearing on 6 days of semi-hardwood showing subsequent development of root initials organized root primordial. $P$. betle is a sensitive-to-root piper species. Lack of regeneration of mature tissues in the stem cuttings reduces the rooting ability of the betel plants. However, the present study showed that $1000-2000 \mathrm{mg} / \mathrm{L}$ of IBA treatments were effective in increasing the rooting percentage of the $P$. betle cuttings. For the adventitious roots initiation and development of betel semi-hardwood cuttings, root primordial was found developed from root initials occurring near the vascular bundle, the phloem and besetting by fiber layers which could hinder its emergence. Nonetheless, IBA applications promote cell expansion and proliferations which are able to break the fiber layers and allow the root primordial to arise.

The results of the tissue culture study showed that the percentage of Clorox with immersing time played a considerable role in inducing shoot sterilization from $P$. betle explants. The use percentage of Clorox with immersing time in an appropriate ratio was the most effective for the shoot induction. The immersing nodes explants in $20 \%$ Clorox for 20 minutes significantly reduced the contamination, and the percentage of the plant survival was the highest $(70.00 \%)$. On the other hand, the BAP at $1.0 \mathrm{mg} / \mathrm{L}$ was the best concentration to induce shoot multiplication from $P$. betle explants. The highest explants with new leaves and the number of axillary buds were attained using the medium containing BAP $(1.0 \mathrm{mg} / \mathrm{L})$. The percentage of the axillary buds was the highest $(22.29 \%)$. Therefore, the medium at $1.0 \mathrm{mg} / \mathrm{L}$ is recommended for the growth of $P$. betle explants during the development and growth of the explants.

\section{References}

[1] Datta, A., Ghoshdastidar, S. and Singh, M. (2011) Antimicrobial Property of Piper betel Leaf against Clinical Isolates of Bacteria. International Journal of Pharma Sciences and Research, 2, 104-109.

[2] Sulaiman, S.F., et al. (2011) Effect of Solvents in Extracting Polyphenols and Antioxidants of Selected Raw Vegetables. Journal of Food Composition and Analysis, 24, 506-515. https://doi.org/10.1016/j.jfca.2011.01.020

[3] Tan, Y.P. and Chan, E.W.C. (2014) Antioxidant, Antityrosinase and Antibacterial Properties of Fresh and Processed Leaves of Anacardium occidentale and Piper betle. Food Bioscience, 6, 17-23. https://doi.org/10.1016/j.fbio.2014.03.001

[4] Pradhan, D., et al. (2013) Golden Heart of the Nature: Piper betle L. Journal of Pharmacognosy and Phytochemistry, 1, No. 6.

[5] Babu, K.N., et al. (1992) Micropropagation of Betel Vine (Piper betle L.). Journal of Spices and Aromatic Crops, 1, 160-162.

[6] Kumar, N., et al. (2010) Piper betle Linn. A Maligned Pan-Asiatic Plant with an Array of Pharmacological Activities and Prospects for Drug Discovery. Current Science, 99, 922-932.

[7] McKey, D., et al. (2010) The Evolutionary Ecology of Clonally Propagated Domes- 
ticated Plants. New Phytologist, 186, 318-332.

https://doi.org/10.1111/j.1469-8137.2010.03210.x

[8] De Klerk, G.-J. (2002) Rooting of Microcuttings: Theory and Practice. In Vitro Cellular \& Developmental Biology-Plant, 38, 415-422.

https://doi.org/10.1079/IVP2002335

[9] Steffens, B., Wang, J. and Sauter, M. (2006) Interactions between Ethylene, Gibberellin and Abscisic acid Regulate Emergence and Growth Rate of Adventitious Roots in Deepwater Rice. Planta, 223, 604-612. https://doi.org/10.1007/s00425-005-0111-1

[10] Kevers, C., et al. (1997) Hormonal Control of Adventitious Rooting: Progress and Questions. Journal of Applied Botany, 71, 71-79.

[11] Haissig, B.E. and Davis, T.D. (1994) A Historical Evaluation of Adventitious Rooting Research to 1993, in Biology of Adventitious Root Formation. Springer, 275-331. https://doi.org/10.1007/978-1-4757-9492-2_19

[12] Han, H., Zhang, S. and Sun, X. (2009) A Review on the Molecular Mechanism of Plants Rooting Modulated by Auxin. African Journal of Biotechnology, 8.

[13] Heloir, M.-C., et al. (1996) Changes in the Concentrations of Auxins and Polyamines during Rooting of In-Vitro-Propagated Walnut Shoots. Tree Physiology, 16, 515-519. https://doi.org/10.1093/treephys/16.5.515

[14] Davies, P.J. (2010) The Plant Hormones: Their Nature, Occurrence, and Functions, in Plant Hormones. Springer, 1-15. https://doi.org/10.1007/978-1-4020-2686-7_1

[15] Tripathi, L. and Tripathi, J.N. (2003) Role of Biotechnology in Medicinal Plants. Tropical Journal of Pharmaceutical Research, 2, 243-253.

[16] Vieitez, A., et al. (2009) In Vitro Regeneration of the Important North American Oak Species Quercus alba, Quercus bicolor and Quercus rubra. Plant Cell, Tissue and Organ Culture (PCTOC), 98, 135-145. https://doi.org/10.1007/s11240-009-9546-6

[17] Ahmad, N., et al. (2010) Efficient Regeneration and Antioxidant Potential in Regenerated Tissues of Piper nigrum L. Plant Cell, Tissue and Organ Culture (PCTOC), 102, 129-134. https://doi.org/10.1007/s11240-010-9712-x

[18] Wu, J.-H., et al. (2009) Factors Affecting the Efficiency of Micropropagation from Lateral Buds and Shoot Tips of Rubus. Plant Cell, Tissue and Organ Culture (PCTOC), 99, 17-25. https://doi.org/10.1007/s11240-009-9571-5

[19] Hartmann, H.T., Kester, D.E., Davies, F.T. and Geneve, R.L. (2002) Plant Propagation: Principles and Practices. Prentice-Hall.

[20] Kalyoncu, I., et al. (2009) Effects of Humidity Level and IBA Dose Application on the Softwood Top Cuttings of White Mulberry (Morus alba L.) and Black Mulberry (Morus nigra L.) Types. African Journal of Biotechnology, 8.

[21] Johansen, D.A. (1940) Plant Microtechnique. McGraw-Hill Book Company, Inc., London, $530 \mathrm{p}$.

[22] Jensen, W.A. (1962) Botanical Histochemistry: Principles and Practice.

[23] Naija, S., et al. (2008) Anatomical and Biochemical Changes during Adventitious Rooting of Apple Rootstocks MM 106 Cultured in Vitro. Comptes rendus biologies, 331, 518-525.

[24] O’Brien, T.P. and McCully, M.E. (1981) The Study of Plant Structure: Principles and Selected Methods. Termarcarphi Pty. Ltd., Melbourne.

[25] Murashige, T. and Skoog, F. (1962) A Revised Medium for Rapid Growth and Bio 
Assays with Tobacco Tissue Cultures. Physiologia plantarum, 15, 473-497. https://doi.org/10.1111/j.1399-3054.1962.tb08052.x

[26] Siddiqui, M.I. and Hussain, S.A. (2007) Effect of Indole Butyric Acid and Types of Cuttings on Root Initiation of Ficus hawaii. Sarhad Journal of Agriculture, 23, 919.

[27] Kochhar, S., et al. (2005) Differential Rooting and Sprouting Behaviour of Two Jatropha Species and Associated Physiological and Biochemical Changes. Current Science, 89, 936-939.

[28] Basak, U., Das, A. and Das, P. (2000) Rooting Response in Stem Cuttings from Five Species of Mangrove Trees: Effect of Auxins and Enzyme Activities. Marine Biolo$g y$, 136, 185-189. https://doi.org/10.1007/s002270050021

[29] LeBude, A.V. (2005) Adventitious Rooting and Physiology of Stem Cuttings of Loblolly Pine.

[30] Harbage, J.F., Stimart, D.P. and Evert, R.F. (1993) Anatomy of Adventitious Root Formation in Microcuttings of Malus domestica Borkh. Gala'. Journal of the American Society for Horticultural Science, 118, 680-688.

[31] Davies Jr, F., Lazarte, J. and Joiner, J. (1982) Initiation and Development of Roots in Juvenile and Mature Leaf Bud Cuttings of Ficus pumila L. American Journal of Botany, 804-811. https://doi.org/10.2307/2442971

[32] Girouard, R.M. (1967) Initiation and Development of Adventitious Roots in Stem Cuttings of Hedera helix: Anatomical Studies of the Juvenile Growth Phase. Canadian Journal of Botany, 45, 1877-1881. https://doi.org/10.1139/b67-202

[33] Lovell, P.H. and White, J. (1986) Anatomical Changes during Adventitious Root Formation. New Root Formation in Plants and Cuttings. Martinus Nijhoff Publishers, Dordrecht, 111-140.

[34] Davies, F.T. (1978) A Histological and Physiological Analysis of Adventitious Root Formation in Juvenile and Mature Cuttings of Ficus pumila L. University of Florida.

[35] Puri, S. and Verma, R. (1996) Vegetative Propagation of Dalbergia sissoo Roxb. using Softwood and Hardwood Stem Cuttings. Journal of Arid Environments, 34, 235-245. https://doi.org/10.1006/jare.1996.0105

[36] Mihaljević, I., et al. (2013) In Vitro Sterilization Procedures for Micropropagation of 'Oblačinska'sour Cherry. Journal of Agricultural Sciences, Belgrade, 58, 117-126. https://doi.org/10.2298/JAS1302117M

[37] Falkiner, F. (1990) The Criteria for Choosing an Antibiotic for Control of Bacteria in Plant Tissue Culture.

[38] Srivastava, N., et al. (2010) Standardization of Sterilization Protocol for Micropropagation of Aconitum heterophyllum-An Endangered Medicinal Herb. Academic Arena, 2, 37-42.

[39] Al-Khayri, J.M. and Al-Bahrany, A.M. (2001) In Vitro Micropropagation of Citrus aurantifolia (lime). Current Science, 1242-1246.

[40] Manickavasagam, M., et al. (2004) Agrobacterium-Mediated Genetic Transformation and Development of Herbicide-Resistant Sugarcane (Saccharum Species Hybrids) using Axillary Buds. Plant Cell Reports, 23, 134-143. https://doi.org/10.1007/s00299-004-0794-y

[41] Košir, P., Škof, S. and Luthar, Z. (2004) Direct Shoot Regeneration from Nodes of Phalaenopsis orchids. Acta Agriculturae Slovenica, 83, 233-242.

[42] Ajithkumar, D. and Seeni, S. (1998) Rapid Clonal Multiplication through in Vitro Axillary Shoot Proliferation of Aegle marmelos (L.) Corr., a Medicinal Tree. Plant Cell Reports, 17, 422-426. https://doi.org/10.1007/s002990050418 
[43] Balaraju, K., Agastian, P. and Ignacimuthu, S. (2009) Micropropagation of Swertia chirata Buch.-Hams. ex Wall.: A Critically Endangered Medicinal Herb. Acta Physiologiae Plantarum, 31, 487-494. https://doi.org/10.1007/s11738-008-0257-0

[44] Sen, M.K., et al. (2014) In Vitro Callus Induction and Plantlet Regeneration of Achyranthes aspera L., a High Value Medicinal Plant. Asian Pacific Journal of Tropical Biomedicine, 4, 40-46. 